P-ISSN 2580 - 7781

E-ISSN 2615 - 3238

\title{
PENGEMBANGAN RUMPUT LAUT BERBASIS KULTUR JARINGAN DI BESUKI
}

\section{DEVELOPMENT OF SEAWEED BASED ON TISSUE CULTURE IN BESUKI}

\author{
Sulistyaningsih $^{1)}$, Yasmini Suryaningsih ${ }^{2)}$ \\ ${ }^{1,2}$ Fakultas Pertanian,Universitas Abdurachman Saleh Situbondo \\ ${ }^{1}$ Email: lis_sulistyaningsih@yahoo.com
}

\begin{abstract}
ABSTRAK
Sektor pertanian dan perikanan memiliki peranan penting di Indonesia karena kedua sektor ini mampu menyediakan lapangan kerja, mampu mendukung sektor industri baik industri hulu maupun industri hilir, mampu menyediakan keragaman menu pangan dan ketersediaan pangan. Salah satu sub sistem agribisnis adalah produksi sektor yang memegang peranan dalam meningkatkan pemenuhan baik secara kuantitas maupun kualitas produk. Rumput laut memiliki potensi ekonomi yang sangat besar dan menjadi salah satu komoditas unggulan di bidang perikanan. Dalam pengembangan budidaya rumput laut hal yang lebih penting adalah memperhatikan sisi keberlanjutan dalam kontinuitas ketersediaan rumput laut. Untuk mendukung hal tersebut diperlukan upayaupaya dalam pengelolaan budidaya rumput laut salah satunya yaitu penggunaan kultur jaringan. Mengingat sebagian besar petani rumput laut di dalam pelaksanaan budidayanya menggunakan bibit yang masih konvensional, dalam artian bahan bibit berasal dari tanaman-tanaman sebelumnya yang disisakan dengan cara hasil panen tidak seluruhnya dijual melainkan sebagian digunakan lagi untuk keperluan bibit dan ini berlangsung terus menerus dan berulang-ulang dilakukan oleh petani termasuk petani rumput laut yang ada di Besuki, Kabupaten Situbondo. Kabupaten Situbondo memiliki potensi dibidang pertanian dan perikanan yang salah satunya adalah potensi budidaya rumput laut. Namun terdapat suatu kendala saat ini jumlah petani yang mengusahakan rumput laut bukannya semakin bertambah malah berkurang. Penurunan ini disebabkan lesunya produksi yang selalu trendnya turun dan harga yang fluktuatif. Hal ini yang mendorong peneliti untuk mengadakan kajian lebih lanjut terkait dengan produksi, pendapatan petani dan efisiensi usaha dalam pengembangan kultur jaringan.
\end{abstract}

Kata Kunci: Rumput laut, Kultur jaringan, Efisiensi

\begin{abstract}
The agriculture and fisheries sectors have an important role in Indonesia because they are able to provide employment, support the industrial sector both upstream and downstream industries, provide variety of food menus and the availability of foods. One of the agribusiness sub-systems is the production sector which plays a role in increasing compliance both in quantity and product quality. Seaweed has enormous economic potential and one of the leading commodities in the field of fisheries. In developing seaweed cultivation, it is more important to pay attention to the sustainability of seaweed. To support this, efforts are needed in the management of seaweed cultivation, such is the use of tissue culture. Considering that most seaweed farmers in their cultivation use conventional seeds in the sense that the seed material comes from previous plants which are left by means of seed yields. Derived from previous plants which are left by means of not all of the harvested seeds are sold, some are used again for seed needs and this is sustainable-continuously and repeatedly carried out by farmers including seaweed
\end{abstract}


P-ISSN $2580-7781$

E-ISSN 2615 - 3238

farmers in Besuki, Situbondo Regency. Situbondo Regency has the potential in agriculture and fisheries such as seaweed cultivation. However, the problem is the decreasing of seaweed's farmers numbers. This decline caused by sluggish production which is always on a downward trend and fluctuating prices. This has prompted researchers to carry out further studies related to production, farmers's income and efficiency of efforts in the development of tissue culture.

Keywords: Seaweed, Tissue culture, Efficiency

\section{PENDAHULUAN}

Hampir semua wilayah pesisir Indonesia dapat dimanfaatkan untuk pengembangan budidaya rumput laut sepanjang masih memenuhi kriteria lokasi untuk kegiatan budidaya. Rumput laut atau juga disebut algae merupakan salah satu produk perikanan unggulan yang memiliki nilai ekonomis dan strategis untuk peluang usaha yang menjanjikan untuk dikembangkan.

Di Indonesia, penyebaran rumput laut berada hampir di seluruh penjuru tanah air, namun produksi dan perdagangan rumput laut Indonesia sampai dengan saat ini didominasi oleh genus Gracilaria, Gelidium, Pterocladia sebagai penghasil agar dan genus Euchema sebagai penghasil karaginan dan genus Sargasum sebagai penghasil alginat.

Rumput laut yang paling berpotensi untuk dikembangkan dan manfaatnya adalah spesies:

1. Euchema cottoni: penghasil karaginan

2. Gracilaria $s p$ : penghasil agar-agar

3. Euchema spinosum: penghasil karaginan

4. Caulerpa sp: anti oksidan, anti hipertensi, rematik, mikroba dan meningkatkan stamina (Anonim, 2019).

Jenis rumput laut komersial yang tumbuh secara alami di berbagai wilayah Indonesia (Djusdil et al, 2019) dan kemanfaatannya secara komersial sebagai berikut: 
P-ISSN 2580 - 7781

E-ISSN 2615 - 3238

Tabel 1. Jenis rumput laut dan potensi kemanfaatannya secara komersial

\begin{tabular}{clc}
\hline Jenis & \multicolumn{1}{c}{ Potensi Komersial } & \multicolumn{1}{c}{ Gambar } \\
\hline Gracilaria sp & $\begin{array}{l}\text { Bahan baku penghasil } \\
\text { agar-agar }\end{array}$ & \\
& & \\
\end{tabular}

Gelidium sp Bahan baku penghasil agar-agar

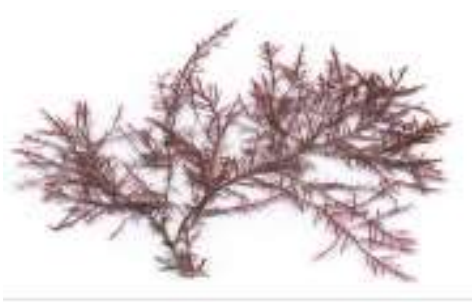

Bahan baku penghasil

Sargassum $\mathrm{sp}$

Alginat yang banyak dibutuhkan dalam industri tekstil.

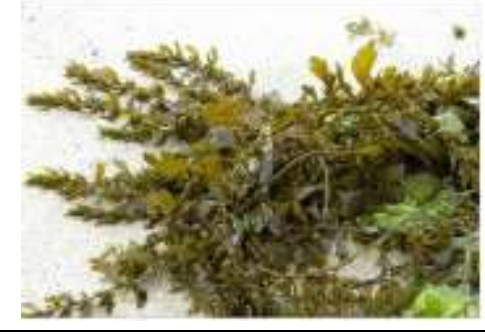

Eucheuma

cottoni

Sebagai bahan baku penghasil Karaginan

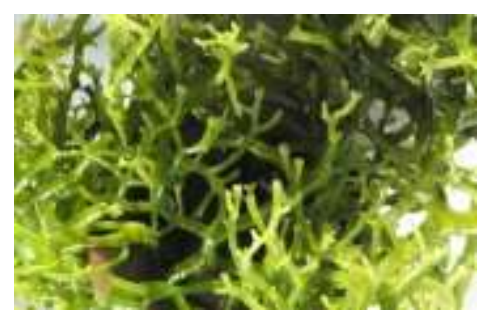

$\begin{array}{ll}\text { Euxheuma } & \text { Sebagai bahan baku } \\ \text { ppinosum } & \text { penghasil Karaginan }\end{array}$

Faktor yang paling sangat mempengaruhi keberhasilan kegiatan budidaya adalah pemilihan lokasi yang harus memperhatikan daya dukung perairan untuk menopang kehidupan dan pertumbuhan rumput laut secara optimal. Selain itu faktor lain yang juga harus dipenuhi adalah lokasi yang sesuai, aksesibilitas yang 
P-ISSN 2580 - 7781

E-ISSN 2615 - 3238

mudah namun jauh dari arus pelayaran, mendapat sumber cahaya matahari yang cukup dan berada di kawasan yang bebas banjir rutin, fluktuasi salinitas, bukan daerah penangkapan ikan dan pencemaran limbah.

Selain lokasi yang harus diperhatikan, prasarana yang diperlukan untuk mendukung kegiatan budidaya rumput laut dapat mencakup sebagai berikut:

1. Tempat penanganan bibit harus tertutup dan terlindungi

2. Konstruksi infrastruktur harus mempertimbangkan fungsi konservasi dan meminimalisasi gangguan terhadap lingkungan sekitar

3. Tempat penanganan panen dan pasca panen harus bebas dari potensi kontaminasi, aman bagi pembudidaya dan tidak merusak lingkungan (Anonim, 2019).

Situbondo merupakan salah satu Kabupaten yang mempunyai potensi sumber daya kelautan dan perikanan cukup besar, khususnya komoditas rumput laut Echeuma cottoni. Dengan potensi ini maka Kabupaten Situbondo melalui sektor kelautan dan perikanan memiliki peluang besar untuk mendorong peningkatan pendapatan daerah. Jenis-jenis rumput laut yang memiliki nilai ekonomis dan telah dibudidayakan adalah Echeuma $s p$ dan Graciliria sp yaitu dari jenis alga merah. Selain itu ada juga Gelidium sp, Sargassum sp dan Turbinaria sp. Echeuma sp dibudidayakan di perairan pantai, sedang Graciliria sp sudah dapat dibudidayakan di tambak.

Budidaya rumput laut di Kabupaten Situbondo sudah lama digalakkan khususnya di Besuki, baik secara tradisional maupun secara intensif dan aktivitas budidaya dilakukan oleh petani di wilayah pesisir Besuki sebagai mata pencaharian utama. Namun di masa pandemi, hanya beberapa orang saja yang tetap melakukan kegiatan budidaya ini.

Kendala dalam pengembangan budidaya rumput laut adalah kualitas bibit rumput laut masih rendah seperti: pertumbuhan kerdil/lambat/tidak maksimal, mudah terserang hama penyakit, mudah tertutupi lumut, tidak tahan terhadap stressor lingkungan serta belum adanya tahapan/proses produksi bibit yang baku (Baedah, 2011). Persoalan mendasar dalam upaya pengembangan rumput laut cottoni pada sektor hulu adalah ketersediaan bibit dalam kuantitas, kualitas dan 
P-ISSN 2580 - 7781

E-ISSN 2615 - 3238

kontinuitas yang memadai. Bibit merupakan faktor produksi yang menduduki urutan pertama sebagai biaya variabel terbesar dalam operasional budidaya (Maryunus dan Hussein, 2018).

Di Besuki sebagian besar petani rumput laut dalam melakukan budidaya rumput laut selalu menggunakan bibit yang diambilkan dari sebagian rumput laut yang telah dipanen dan itu dilakukan secara berulang, sehingga mengakibatkan penurunan produksi sebab tidak jarang bibit yang digunakan kemungkinan tidak sehat, sebagaimana diungkap oleh Hurtado dan Cheney dalam Mulyaningrum (2018). Pemakaian bibit dari sumber yang sama secara berulang-ulang akan berakibat terjadinya "pelunturan genetika", yang berdampak terhadap menurunnya produktivitas, menurunnya kandungan karagenan dan kekuatan gel serta meningkatnya kerentanan terhadap penyakit. Salah satu upaya dalam peningkatan produksi rumput laut yaitu penggunaan kultur jaringan cottoni (Kappaphycus alvarezii).

\section{METODE}

Pendekatan penelitian ini dilakukan dengan metode survey dan operasional (action research). Riset dengan survey pada penelitian ini meliputi identifikasi pada obyek penelitian. Pendekatan secara operasional (action research) akan diimplementasikan dan diuji pengaruhnya terhadap peningkatan pendapatan. Analisis Pendapatan menggunakan rumus $\boldsymbol{\pi}=\mathbf{T R}-\mathbf{T C}$. Efisiensi menggunakan rumus RCR (Revenue Cost Ratio) $: \mathbf{R C R}=\frac{T R}{T C}$.

\section{HASIL PENELITIAN DAN PEMBAHASAN}

Saat dilakukan penelitian banyak petani rumput laut yang tidak melakukan kegiatan penanaman dan hanya beberapa saja yang masih menanam. Dari populasi \pm 45 orang, 3 orang petani rumput laut dengan kultur jaringan dan 8 orang petani non kulltur jaringan. Sehingga metode pengambilan sampel yang semula direncanakan 30 orang berdasarkan Roescoe (Sugiono, 2009) berubah menjadi metode sensus. Hal ini dengan pertimbangan karena hanya sebagian petani rumput laut yang masih melakukan kegiatan. Alasan mereka tidak melakukan penanaman karena permintaan pasar sedang lesu atau sama sekali 
P-ISSN 2580 - 7781

E-ISSN 2615 - 3238

tidak ada permintaan pasar. Ini terjadi sebelum adanya wabah Covid-19 dan sampai wabah Covid-19 ini menyerang di seluruh dunia tanpa terkecuali Indonesia dan khususnya Situbondo, dari mereka yang tetap menanam hanya untuk dikeringkan dan disimpan apabila sewaktu-waktu ada permintaan, mereka akan jual kembali.

Di Besuki - Kabupaten Situbondo khususnya dusun Mandaran banyak petani menerapkan metode penanaman dengan model rakit apung (model ancak) baik yang mengunakan kultur jaringan maupun non kultur jaringan. Dimulai dengan mengikat bibit rumput laut ke tali kecil (tali ris dengan ukuran $3 \mathrm{~mm}$ ) kemudian pada tali ris tersebut, setiap jarak 10-15 cm dibuat tali cincin (ukuran 1 $\mathrm{mm}$ ) dimana bibit rumput laut tersebut diikat. Kegiatan ini yang disebut dengan nyandik. Pada saat pengikatan bibit sebaiknya dilakukan di lokasi yang terlindung dari sinar matahari langsung agar bibit tidak mengalami kekeringan. Umumnya masyarakat Besuki khususnya dusun Mandaran melakukan kegiatan nyandik di halaman rumah atau di tepi pantai di bawah pohon. Jarak tanam 10-15 cm dan jarak antar tanaman $\pm 30 \mathrm{~cm}$. Bibit rumput laut ditanam pada kedalaman $20-30 \mathrm{~cm}$ dari permukaan air laut.

Pemeliharaan. Merupakan keharusan agar usaha budidaya ini berhasil. Kegiatan pemeliharaan berupa pengontrolan secara rutin, biasanya petani dengan menggunakan ban dalam truk bekas untuk dijadikan perahu-perahu kecil, sambil dinaiki oleh mereka untuk membersihkan kotoran maupun penyulaman. Pemeliharaan dilakukan sesering mungkin. Umumnya para petani melakukan pengontrolan tiap minggu untuk membersihkan dan menjaga agar rumput laut terhindar dari tanaman pengganggu maupun kotoran yang melekat serta melakukan kegiatan penyulaman terhadap tanaman yang terlepas. Khusus untuk kegiatan penyulaman hanya dilakukan pada minggu pertama setelah rumput laut ditanam.

Pemanenan. Dilakukan saat rumput laut berusia 40 hari bila ingin dijual basah karena pada usia tersebut kandungan karagenan optimal sesuai dengan permintaan pasar untuk kebutuhan industri. Namun manakala dijual kering maka umur rumput laut sebaiknya 45 hari atau lebih karena pada umur tersebut 
P-ISSN 2580 - 7781

E-ISSN 2615 - 3238

kandungan karaginan cukup tersedia. Pengeringan membutuhkan waktu 3-5 hari bila cuaca terik dan bila cuaca agak mendung maka membutuhkan waktu yang lebih lama. Penjemuran yang baik dilakukan diatas para-para namun kebanyakan petani menjemur di pinggir-pinggir pantai dengan beralaskan paranet.

\section{Pendapatan dan Efisiensi Usahatani Rumput Laut Kultur Jaringan dan non}

\section{Kultur Jaringan.}

Berdasarkan penelitian di lokasi Besuki-Mandaran terdapat 2 kelompok tani rumput laut yang menggunakan kultur jaringan dan yang tidak menggunakan atau non kultur jaringan, diperoleh hasil bahwa :

A. Pada awal tanam siklus pertama Tabel 2:

1. Untuk petani yang menggunakan bibit dengan kultur jaringan sebanyak 3 orang, rata-rata produksi sebesar $3,619 \mathrm{~kg}$ dan rata-rata pendapatan sebesar Rp. 405,000 sedangkan rata-rata nilai RCR sebesar 1.082. Hal ini menunjukkan bahwa usahatani rumput laut tersebut dengan kultur jaringan efisien dan layak untuk dilaksanakan.

2. Sedangkan untuk petani rumput laut non kultur jaringan sebanyak 8 orang, rata-rata produksi sebesar $3,542 \mathrm{~kg}$ dan rata-rata pendapatan sebesar $\mathrm{Rp}$. 131,813 sedangkan rata-rata nilai RCR sebesar 1.024. Hal ini menunjukkan bahwa usahatani rumput laut tersebut non kultur jaringan juga efisien dan layak untuk dilaksanakan.

3. Pada siklus pertama atau awal tanam baik petani yang menggunakan kultur jaringan dan yang non kultur jaringan keduanya sama-sama efisien karena nilai RCR > 1, namun bila diperbandingkan maka terdapat selisih nilai RCR sebesar 0,058 lebih besar dari yang menggunakan kultur jaringan, artinya bahwa produksi rumput laut dengan kultur jaringan produksinya lebih tinggi.

B. Prediksi hasil pada tanam siklus/periode kedua Tabel 3 sebagai berikut:

Untuk periode ke dua ini ada perubahan pada penggunaan biaya yaitu pada komponen bambu, tali $3 \mathrm{~mm}$ dan $4 \mathrm{~mm}$ serta tali yang digunakan untuk jangkar. Petani tidak lagi membeli bahan-bahan tersebut karena dapat digunakan kembali. Mereka menggunakan ulang dari yang sebelumnya, bahkan bisa 5-6 kali 
P-ISSN 2580 - 7781

E-ISSN 2615 - 3238

pemakaian, sehingga total biaya lebih rendah dan ini akan berpengaruh kepada pendapatan dan nilai efisiensi.

1. Untuk petani yang menggunakan bibit kultur jaringan, dengan rata-rata produksi yang sama yakni 3,619 kg sedangkan rata-rata pendapatan sebesar Rp. 2,129,000 dan rata-rata nilai RCR sebesar 1.647. Hal ini menunjukkan bahwa usahatani rumput laut tersebut dengan kultur jaringan efisien dan layak untuk dilaksanakan.

2. Sedangkan untuk petani rumput laut non kultur jaringan dengan rata-rata produksi 3,542 $\mathrm{kg}$ dan rata-rata pendapatan $\mathrm{Rp}$. 1,909,688. Sedangkan nilai RCR sebesar 1.559. Hal ini menunjukkan bahwa usahatani rumput laut tersebut non kultur jaringan juga efisien dan layak untuk dilaksanakan.

3. Pada siklus ke dua/ periode ke dua tanam baik petani yang menggunakan kultur jaringan dan yang non kultur jaringan keduanya sama-sama efisien karena nilai RCR > 1, namun bila diperbandingkan maka terdapat selisih nilai RCR sebesar 0,088 lebih besar dari yang menggunakan kultur jaringan, artinya bahwa produksi rumput laut dengan kultur jaringan produksinya lebih tinggi.

Tabel 2. Analisis usahatani rumput laut periode I (awal tanam)

\begin{tabular}{|c|c|r|r|r|r|r|}
\hline $\begin{array}{c}\text { No } \\
\text { Responden }\end{array}$ & $\begin{array}{c}\text { Total } \\
\text { Biaya } \\
(\mathrm{TC})\end{array}$ & $\begin{array}{c}\text { Produksi } \\
(\mathrm{Q})\end{array}$ & $\begin{array}{c}\text { Harga } \\
(\mathrm{P})\end{array}$ & $\begin{array}{c}\text { Penerimaan } \\
(\mathrm{TR})\end{array}$ & $\begin{array}{c}\text { Pendapatan } \\
(\pi)\end{array}$ & $\begin{array}{c}\text { Efisiensi } \\
(\mathrm{RCR})\end{array}$ \\
\hline \multicolumn{7}{|c|}{ Petani Kultur Jaringan $(1-3)$} \\
\hline 1 & $7,536,000$ & 5,358 & 1,500 & $8,037,000$ & 501,000 & 1.066480892 \\
\hline 2 & $5,024,000$ & 3,700 & 1,500 & $5,550,000$ & 526,000 & 1.104697452 \\
\hline 3 & $2,512,000$ & 1,800 & 1,500 & $2,700,000$ & 188,000 & 1.074840764 \\
\hline Rata-rata & $5,024,000$ & 3,619 & 1,500 & $5,429,000$ & 405,000 & 1.082006369 \\
\hline \multicolumn{7}{|c|}{ Petani Non Kultur Jaringan $(4-11)$} \\
\hline 4 & $6,280,000$ & 4,250 & 1,500 & $6,375,000$ & 95,000 & 1.015127389 \\
\hline 5 & $5,024,000$ & 3,685 & 1,500 & $5,527,500$ & 503,500 & 1.100218949 \\
\hline 6 & $7,536,000$ & 5,100 & 1,500 & $7,650,000$ & 114,000 & 1.015127389 \\
\hline 7 & $5,024,000$ & 3,400 & 1,500 & $5,100,000$ & 76,000 & 1.015127389 \\
\hline 8 & $2,512,000$ & 1,700 & 1,500 & $2,550,000$ & 38,000 & 1.015127389 \\
\hline 9 & $3,768,000$ & 2,400 & 1,500 & $3,600,000$ & $-168,000$ & 0.955414013 \\
\hline 10 & $6,280,000$ & 4,200 & 1,500 & $6,300,000$ & 20,000 & 1.003184713 \\
\hline 11 & $5,024,000$ & 3,600 & 1,500 & $5,400,000$ & 376,000 & 1.074840764 \\
\hline Rata-rata & $1,369,500$ & 3,542 & 1,500 & $5,312,813$ & 131,813 & 1.024270999 \\
\hline
\end{tabular}

(Sumber data primer diolah, 2020) 
P-ISSN $2580-7781$

E-ISSN 2615 - 3238

Tabel 3. Analisis usahatani rumput laut periode II (tanam kedua)

\begin{tabular}{|c|c|r|r|r|r|r|}
\hline $\begin{array}{c}\text { No } \\
\text { Responden }\end{array}$ & $\begin{array}{c}\text { Total } \\
\text { Biaya } \\
(\mathrm{TC})\end{array}$ & $\begin{array}{c}\text { Produksi } \\
(\mathrm{Q})\end{array}$ & $\begin{array}{c}\text { Harga } \\
(\mathrm{P})\end{array}$ & $\begin{array}{c}\text { Penerimaan } \\
(\mathrm{TR})\end{array}$ & $\begin{array}{c}\text { Pendapatan } \\
(\pi)\end{array}$ & $\begin{array}{c}\text { Efisiensi } \\
(\mathrm{RCR})\end{array}$ \\
\hline \multicolumn{7}{|c|}{ Petani Kultur Jaringan $(1-3)$} \\
\hline 1 & $4,950,000$ & 5,358 & 1,500 & 8037000 & $3,087,000$ & 1.623636 \\
\hline 2 & $3,300,000$ & 3,700 & 1,500 & 5550000 & $2,250,000$ & 1.681818 \\
\hline 3 & $1,650,000$ & 1,800 & 1,500 & 2700000 & $1,050,000$ & 1.636364 \\
\hline Rata-rata & $3,300,000$ & 3,619 & 1,500 & 5429000 & $2,129,000$ & 1.647273 \\
\hline \multicolumn{7}{|c|}{ Petani Non Kultur Jaringan (4-11) } \\
\hline 4 & $4,125,000$ & 4,250 & 1,500 & 6375000 & $2,250,000$ & 1.545455 \\
\hline 5 & $3,300,000$ & 3,685 & 1,500 & 5527500 & $2,227,500$ & 1.675 \\
\hline 6 & $4,950,000$ & 5,100 & 1,500 & 7650000 & $2,700,000$ & 1.545455 \\
\hline 7 & $3,300,000$ & 3,400 & 1,500 & 5100000 & $1,800,000$ & 1.545455 \\
\hline 8 & $1,650,000$ & 1,700 & 1,500 & 2550000 & 900,000 & 1.545455 \\
\hline 9 & $2,475,000$ & 2,400 & 1,500 & 3600000 & $1,125,000$ & 1.454545 \\
\hline 10 & $4,125,000$ & 4,200 & 1,500 & 6300000 & $2,175,000$ & 1.527273 \\
\hline 11 & $3,300,000$ & 3,600 & 1,500 & 5400000 & $2,100,000$ & 1.636364 \\
\hline Rata-rata & $3,403,125$ & 3,542 & 1,500 & $5,312,813$ & $1,909,688$ & 1.559375 \\
\hline
\end{tabular}

(Sumber data primer diolah, 2020)

\section{KESIMPULAN}

1. Rata-rata pendapatan usahatani kultur jaringan lebih besar dari non kultur jaringan sebesar Rp. 273.187 pada siklus/periode awal dan pada siklus/periode ke dua Rp 219.312

2. Petani yang menggunakan kultur jaringan pada siklus/periode pertama rata-rata lebih efisien 0,058 dibandingkan dengan yang non kultur jaringan. Demikian pula pada siklus/periode ke dua lebih efisien sebesar 0.088 artinya kultur jaringan lebih layak untuk di kembangkan.

\section{DAFTAR PUSTAKA}

Anonim. 2019. Potensi Pengembangan dan Persyaratan Budidaya Rumput Laut. https://kkp.go.id/SKPT/Sumba_Timur/artikel/12801-4. Diakses Juli 2020.

Anonim. 2013. Teknik Budidaya Rumput Laut Euchema cottonii dengan Model Terapung. http://infotanam.blogspot.co.id/2013/10/teknik-budidayarumput-laut-euchema.html. Diakses 20 Juli 2020. 
P-ISSN $2580-7781$

E-ISSN 2615 - 3238

Baedah, M. A. 2011. Perlunya Standar Operasional Prosedur (SPO) Pengadaan Bibit Rumput Laut di Sulawesi Tengah. Makalah. Palu: Dinas Kelautan dan Perikanan Provinsi Sulawesi Tengah.

Djusdil Akrim, Gufron D. Dirawan, Bakhrani A. Rau. 2019. Perkembangan Budidaya Rumput Laut Dalam Meningkatkan Perekonomian Masyarakat Pesisir Di Indonesia. UNM Environmental Journals, Volume 2 Nomor 2 April 2019 Hal. 52 - 56, p-ISSN: 2598-6090 dan e-ISSN: 2599-2902

Hurtado, A.Q., \& Cheney, D.P. 2003. Propagule Production of Eucheuma denticulatum (Burman) Collins et Harvey by Tissue Culture. Bot. Mar., 46(4):338-341.

Mulyaningrum, S. R. H. 2018. Mengapa perlu kultur jaringan rumput laut

Maryunus, R. P. dan Hussein, R. 2018. Performansi Pertumbuhan Bibit Kultur Jaringan Rumput Laut Kotoni (Kappaphycus alvarezii) Di Perairan Teluk Vid Bangir, Jurnal Akuatika Indonesia Vol. 3 No. 2/ September 2018 (91-95)

Soekartawi. 1995. Analisis Usahatani. UI. Jakarta.

Sugiyono. 2009. Statistik Non Parametrik. Bandung. Alfabeta 